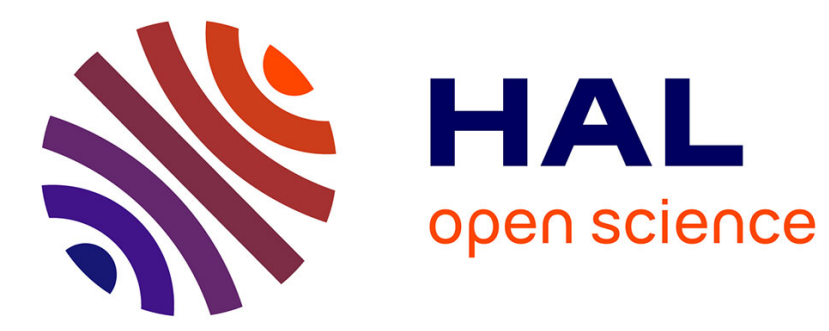

\title{
Flow-alignment and the sign of $\kappa 2$ in nematic liquid crystals
}

\author{
W.W. Beens, W.H. de Jeu
}

\section{To cite this version:}

W.W. Beens, W.H. de Jeu. Flow-alignment and the sign of $\kappa 2$ in nematic liquid crystals. Journal de Physique Lettres, 1983, 44 (19), pp.805-809. 10.1051/jphyslet:019830044019080500 . jpa-00232266

\section{HAL Id: jpa-00232266 https://hal.science/jpa-00232266}

Submitted on 1 Jan 1983

HAL is a multi-disciplinary open access archive for the deposit and dissemination of scientific research documents, whether they are published or not. The documents may come from teaching and research institutions in France or abroad, or from public or private research centers.
L'archive ouverte pluridisciplinaire HAL, est destinée au dépôt et à la diffusion de documents scientifiques de niveau recherche, publiés ou non, émanant des établissements d'enseignement et de recherche français ou étrangers, des laboratoires publics ou privés. 


\title{
LE JOURNAL DE PHYSIQUE-LETTRES
}

J. Physique - LETTRES 44 (1983) L-805 - L-809

1er OCTOBRe 1983, PAGE L-805

Classification

Physics Abstracts

$61.30-47.15$

\section{Flow-alignment and the sign of $\kappa_{2}$ in nematic liquid crystals}

\author{
W. W. Beens and W. H. de Jeu \\ Solid State Physics Laboratory, University of Groningen, \\ Melkweg 1, 9718 EP Groningen, The Netherlands
}

(Reçu le 10 juin 1983, accepté le 9 août 1983)

\begin{abstract}
Résumé. - On présente des résultats pour $\theta_{0}$, l'angle d'alignement des nématiques par l'écoulement. Des mesures sur deux composés qui ne diffèrent que dans la présence d'un groupe de cyano terminal fortement polaire, n'indiquent aucune influence de ce groupe sur $\theta_{0}$. Des résultats pour une série homologue montrent que $\theta_{0}$ décroît avec la longueur des chaînes d'alkyl, jusqu'à perdre l'alignement en raison d'un changement du signe de $\kappa_{2}$. Ces effets sont attribués à l'ordre smectique prétransitionnel.
\end{abstract}

\begin{abstract}
Results are presented for the flow-alignment angle $\theta_{0}$ of various nematics. Measurements for two compounds that differ mainly in the presence of a strongly polar terminal cyano-group indicate that this has no influence on $\theta_{0}$. Results for a homologous series give a decrease of $\theta_{0}$ with increasing alkyl chain lengths, until finally no flow-alignment exists due to a change in sign of $\kappa_{2}$. This is attributed to pre-transitional smectic order.
\end{abstract}

The hydrodynamic properties of nematic liquid crystals [1] are complicated in the first place because the flow depends on the angles between the preferred orientation of the long molecular axis (director $\mathbf{n}$ ) and the flow direction $\mathbf{v}$ and the velocity gradient $\nabla \mathbf{v}$. Secondly, translational motions are coupled to inner, orientational motions of the molecules and the flow will cause $\mathbf{n}$ to rotate. In the absence of external constraints this leads to flow-alignment, which means that $\mathbf{n}$ orientates in the shear-plane at an angle $\theta_{0}$ with respect to $\mathbf{v}$. The flow-alignment angle $\theta_{0}$ is given by [2]

$$
\tan ^{2} \theta_{0}=-\kappa_{2} / \kappa_{1}
$$

where $\kappa_{1}$ (or $\alpha_{2}$ ) and $\kappa_{2}$ (or $-\alpha_{3}$ ) are the shear-torque coefficients that determine the torques on $\mathbf{n}$ when it is parallel to $\nabla \mathbf{v}$ and $\mathbf{v}$, respectively. These shear-torque coefficients are of special interest because they have no isotropic counterpart. For some nematogenic compounds $\kappa_{2}$ has been found to change sign as a function of temperature [3]. In that case there is no real solu- 
tion to equation 1 anymore. It is the purpose of this letter to report on the physical origin of this effect. In particular it will be shown that it is not related to association between strongly polar molecules as has been suggested $[3 a, 4]$. It is due to the influence of smectic short-range order on $\kappa_{2}$ [5], for which flow-alignment turns out to be an extremely sensitive probe.

The set-up used to determine $\theta_{0}$ is essentially as described in reference 6 . The optical detection system has been improved along similar lines as used by Lim et al. [7] to determine the birefringence of liquid crystals. Referring to figure 1 we note that the light emerging from the sample is elliptically polarized, with a phase shift $\delta$ between the components parallel and perpendicular

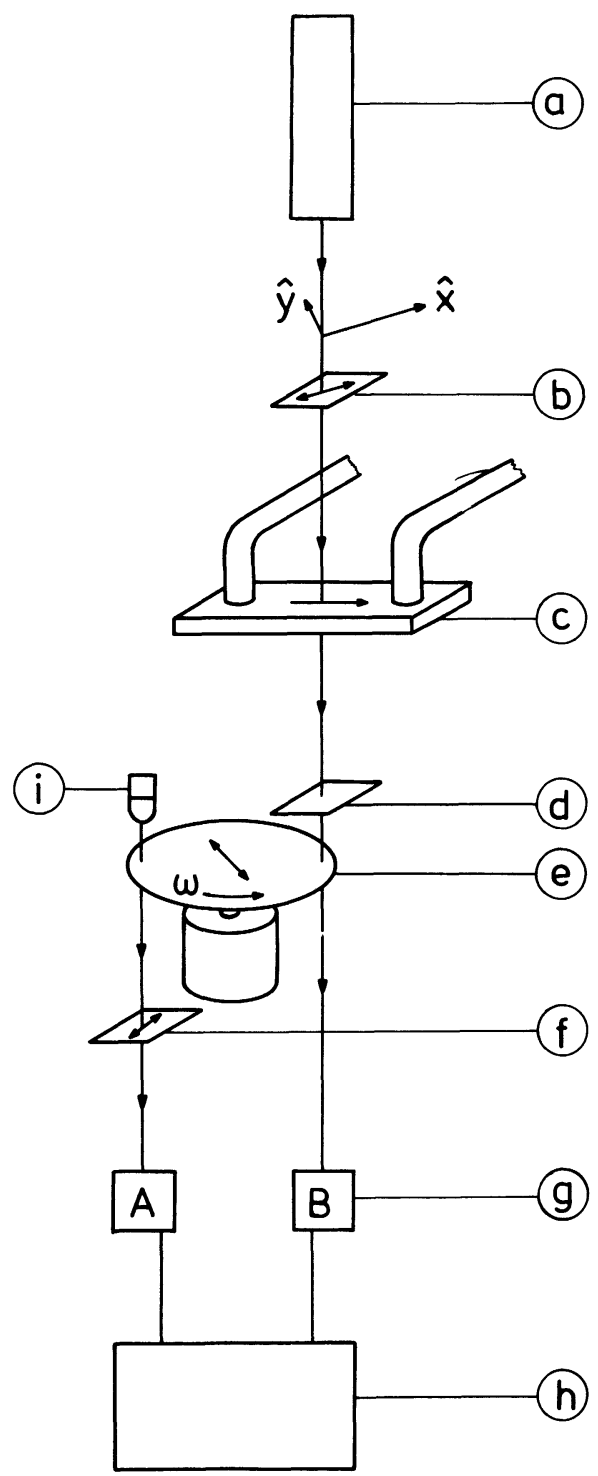

Fig. 1. - The optical part of the set-up used to determine $\theta_{0}$. a - He-Ne laser, $\mathrm{b}-$ polarizer, $\mathrm{c}-$ flowcell, $\mathrm{d}-\lambda$ /4-plate, $\mathrm{e}$ - rotating polaroid, $\mathrm{f}$ - analyser, $\mathrm{g}$ - photodiodes, $\mathrm{h}$ - phase meter, $\mathrm{i}-\mathrm{LED}$. 
to $\mathbf{n}$, respectively. The intensities of the reference beam $\left(I_{\mathrm{A}}\right)$ and of the light beam from the sample $\left(I_{\mathbf{B}}\right)$ are given by

$$
\begin{aligned}
& I_{\mathrm{A}}=I_{1}[1+\cos (2 \omega t)] \\
& I_{\mathrm{B}}=I_{2}[1+\cos (2 \omega t+\delta)],
\end{aligned}
$$

where $\omega$ is the frequency of the rotating polaroid. This allows us to measure the change $\Delta \delta$ in the phase shift $\delta$ comparing the situations $\mathbf{n} / / \mathbf{v}$ (using an external magnetic field) and $\mathbf{n}$ at $\theta_{0}$ with $\mathbf{v}$ (field switched off). Now, $\Delta \delta$ is given for a parabolic velocity distribution by $[3 a, 6]$

$$
\Delta \delta=-\frac{\pi}{\lambda} n_{\mathrm{e}} d\left[\left(n_{\mathrm{e}} / n_{\mathrm{o}}\right)^{2}-1\right] \sin ^{2} \theta_{0}
$$

Here $n_{\mathrm{o}}$ and $n_{\mathrm{e}}$ are the ordinary and extraordinary refractive index, respectively, at a wavelength $\lambda$, while $d$ is the thickness of the flow cell. In the derivation of equation 3 the optical effect of the boundary layers and of the transition layer in the middle of the cell has been neglected. Furthermore it has been assumed that $\sin ^{2} \theta_{0} \ll 1$. Thus, $\theta_{0}$ can be determined from $\Delta \delta$ by means of equation 3.

The compounds investigated are given in table $I$, together with their transition temperatures. The first two differ in the presence or absence of a strongly polar CN-group; otherwise they are as similar as possible. This should allow the observation of any effect of molecular association on the flow-alignment, as this association is directly connected with the presence of a strongly polar end group [4]. The other compounds serve to investigate any effect of increasing smectic order in a homologous series, which is expected with increasing alkyl chain length.

Table I. - Compounds studied.

1.<smiles>N#Cc1ccc(OC2(Oc3ccc(S)cc3)CCCCCC2)cc1</smiles>

2.<smiles>COc1ccc(OC(=O)C2CCC(S)CC2)cc1</smiles>

3.<smiles>N#Cc1ccc(-c2ccc([AlH2][SbH3])cc2)cc1</smiles>

4.<smiles>[13CH2][13c]1ccc(-c2ccc(C#N)cc2)cc1</smiles>

5.

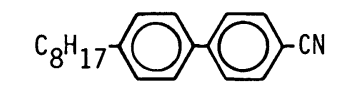

K 47.6 N 79.5 I K $40 \mathrm{~N} \mathrm{71,8} \mathrm{I}$ K 24 N 34.7 I K $30 \mathrm{~N} \mathrm{42,7} \mathrm{I}$ 
The results for $\theta_{0}$ of the two esters are given in figure 2. Within the experimental error they have the same values, excluding any important effect of anti-parallel molecular association on the flow-alignment. The results of the $n \mathrm{CB}$-series are given in figure 3 . Here we note a trend of decreasing $\theta_{0}$ with increasing chain length, until finally for $8 \mathrm{CB}$ the flow-alignment disappears $\left(\kappa_{2}\right.$ changes sign) about $1^{0}$ below the nematic-isotropic transition. There has been some disagreement about the (non)-existence of flow-alignment in $7 \mathrm{CB}[3 f, 8]$. Our measurements do not give any evidence for a change of sign of $\kappa_{2}$ in that case. The trend of decreasing $\theta_{0}$ with increasing alkyl chain length was also found for the series of $p, p^{\prime}$-dialkylazoxybenzenes. This will be reported elsewhere in combination with results of a homologous series without smectic phases.

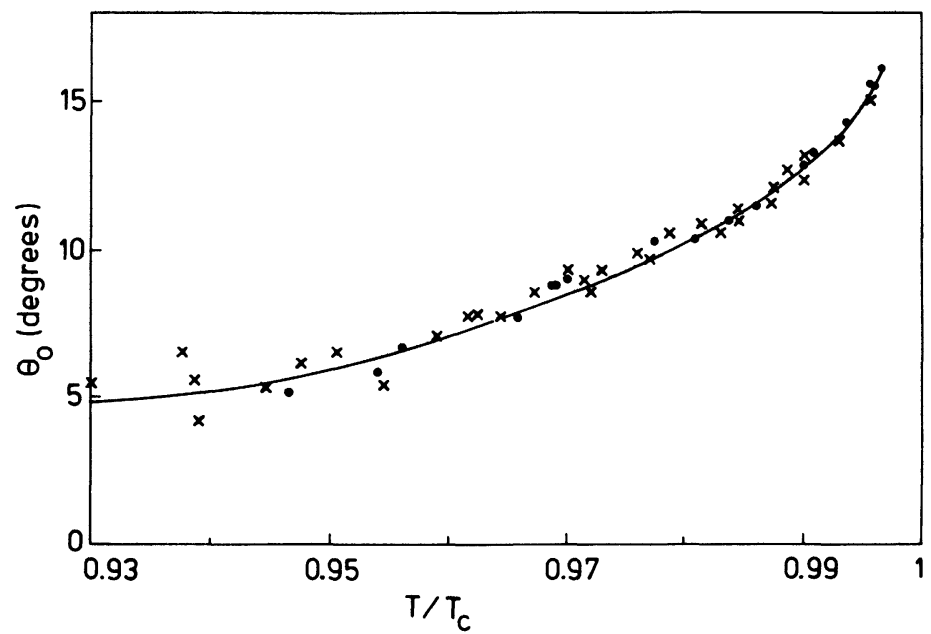

Fig. 2. - Flow-alignment angle of compound $1(\bullet)$ and $2(x)$.

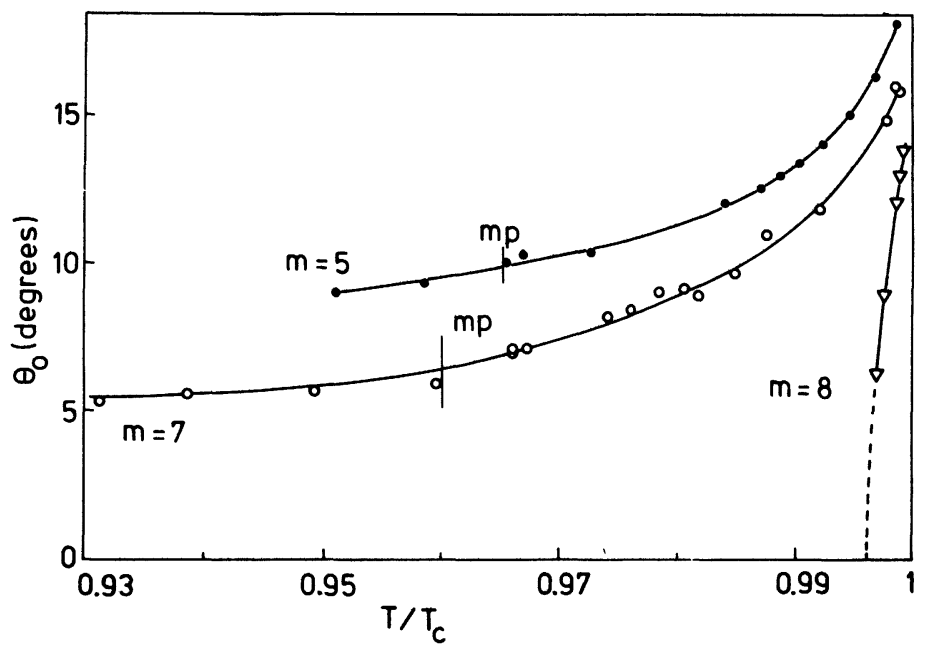

Fig. 3. - Flow-alignment angle of 5CB (๑), 7CB (O) and 8CB ( $\nabla)$.

From time-dependent Landau theory a renormalization of $\kappa_{2}$ due to pre-transitional shortrange smectic order is predicted [5], finally leading to $\kappa_{2}$ diverging in the smectic phase. On 
the other hand, $\kappa_{1}$ is not sensitive to this effect. The divergence is well-known from measurements of $\gamma_{1}=\kappa_{1}+\kappa_{2}$ [9]. However, for rod-like nematogenic molecules $\kappa_{1}$ is necessarily positive [10], and usually one or two orders of magnitude larger than $\left|\kappa_{2}\right|$. Hence $\gamma_{1}$ is rather insensitive to changes in $\kappa_{2}$, in contrast to the flow-alignment angle $\theta_{0}$. This latter quantity provides an extremely sensitive and useful probe for smectic short-range order, which might even be found without a smectic phase actually having been observed.

\section{Acknowledgments.}

This work forms part of the research programme of the «Stichting voor Fundamenteel Onderzoek der Materie » (Foundation for Fundamental Research on Matter - FOM) and was made possible by financial support from the « Nederlandse Organisatie voor Zuiver-Wetenschappelijk Onderzoek » (Netherlands Organization for the Advancement of Pure Research - ZWO).

\section{References}

[1] See, for example, DE Gennes, P. G., The Physics of Liquid Crystals (Clarendon, Oxford) 1974.

[2] See, for example, DE Jeu, W. H., Physical Properties of Liquid Crystalline Materials (Gordon and Breach, New York) 1980, chap. 7.

[3] (a) GäHWIller, Ch., Phys. Rev. Lett. 28 (1972) 1554.

(b) Pieranski, P. and Guyon, E., Phys. Rev. Lett. 32 (1974) 924.

(c) Cladis, P. E. and Torza, S., Phys. Rev. Lett. 35 (1975) 1283.

(d) Kim, M. G., Park, S., Cooper, Sr. M. and Letcher, S. V., Mol. Cryst. Liq. Cryst. 36 (1976) 143.

(e) Sharp, K., Carlsson, T., Lagerwall, S. T. and Stebler, B., Mol. Cryst. Liq. Cryst. 66 (1981) 199.

(f) Clark, M. G., Saunders, F. C. and Shanks, I. A., Mol. Cryst. Liq. Cryst. 70 (1981) 195.

[4] De JeU, W. H., Philos. Trans. R. Soc. London A 309 (1983) 217.

[5] (a) McMillan, W. L., Phys. Rev. A 9 (1974) 1720.

(b) JÄHNIG, F. and Brochard, F., J. Physique 35 (1974) 301.

[6] BeEns, W. W. and DE JeU, W. H., J. Physique 44 (1983) 129.

[7] Lim, K. C. and Ho, J. T., Mol. Cryst. Liq. Cryst. 47 (1978) 173.

[8] (a) Skarp, K., Carlsson, T., Dahl, I., Lagerwall, S. T. and Stebler, B., Advances in Liquid Crystal Research and Applications, edited by L. Bata (Pergamon, Oxford) 1980, p. 573.

(b) Hunnisett, S. D. and VAn Der SluiJs, J. C. A., J. Physique Lett. 44 (1983) L-59.

[9] (a) Hardouin, F., Achard, M. F., Sigaud, G. and Gasparoux, H., Phys. Lett. 49A (1974) 25.

(b) Huang, C. C., Pindak, R. S., Flanders, P. J. and Ho, J. T., Phys. Rev. Lett. 33 (1974) 400.

(c) Kneppe, H., Schneider, F. and Sharma, N. K., J. Chem. Phys. 77 (1982) 3203.

[10] LeSLie, F. M., Q. J. Mech. Appl. Math. 19 (1966) 357. 